\title{
Review Article \\ Pivotal Roles of GM-CSF in Autoimmunity and Inflammation
}

\author{
Aoi Shiomi and Takashi Usui \\ Department of Rheumatology and Clinical Immunology, Graduate School of Medicine, Kyoto University, Kyoto 606-8507, Japan
}

Correspondence should be addressed to Takashi Usui; takausui@kuhp.kyoto-u.ac.jp

Received 5 January 2015; Accepted 23 February 2015

Academic Editor: Fulvio D’Acquisto

Copyright (C) 2015 A. Shiomi and T. Usui. This is an open access article distributed under the Creative Commons Attribution License, which permits unrestricted use, distribution, and reproduction in any medium, provided the original work is properly cited.

Granulocyte macrophage-colony stimulating factor (GM-CSF) is a hematopoietic growth factor, which stimulates the proliferation of granulocytes and macrophages from bone marrow precursor cells. In autoimmune and inflammatory diseases, Th17 cells have been considered as strong inducers of tissue inflammation. However, recent evidence indicates that GM-CSF has prominent proinflammatory functions and that this growth factor (not IL-17) is critical for the pathogenicity of CD $4^{+} \mathrm{T}$ cells. Therefore, the mechanism of GM-CSF-producing CD4 ${ }^{+} \mathrm{T}$ cell differentiation and the role of GM-CSF in the development of autoimmune and inflammatory diseases are gaining increasing attention. This review summarizes the latest knowledge of GM-CSF and its relationship with autoimmune and inflammatory diseases. The potential therapies targeting GM-CSF as well as their possible side effects have also been addressed in this review.

\section{Introduction}

Granulocyte macrophage colony-stimulating factor (GMCSF) is a hematopoietic growth factor which was originally recognized as a stimulator for the proliferation of granulocytes and macrophages from bone marrow precursor cells [1]. It has also been shown to promote the survival and activation of mature myeloid cells and therefore contributes to the maintenance of innate immune homeostasis [2]. Recent studies suggest that GM-CSF also has proinflammatory functions and plays critical roles in the development of autoimmune and inflammatory diseases, particularly in Th17 driven diseases $[3,4]$.

\section{Biology of GM-CSF}

2.1. Production of GM-CSF. GM-CSF is produced by a variety of cells. Major sources of GM-CSF include activated T and B cells, monocytes/macrophages, endothelial cells, fibroblasts, and other sources such as neutrophils, eosinophils, epithelial cells, mesothelial cells, chondrocytes, Paneth cells, and tumor cells [5-7]. The production of GM-CSF in T cells is stimulated by IL- $1 \beta$ and IL-23 in mice $[3,8]$, IL- $1 \beta$ and IL- 12 in humans [9], and also prostaglandin E2 [10]. In fibroblasts, endothelial cells, chondrocytes, and smooth muscle cells, it is stimulated by TNF- $\alpha$ and IL-1, and in macrophage/monocytes it is stimulated by toll like receptors (TLRs) [5]. In lymphocytes, the transcription factor nuclear factor of activated $\mathrm{T}$ cells (NFAT) is reported to be required for the production of GM-CSF [11, 12]. However, the production of GM-CSF can be inhibited by IFN- $\gamma$ [13], IL-4 [14], IL-10 [15], and also pharmacological agents such as cyclosporine A $[16,17]$ or glucocorticoids [18].

2.2. GM-CSF Receptor and Signaling. The GM-CSF receptor is expressed on myeloid cells and on some nonhaemopoietic cells such as endothelial cells but not on $\mathrm{T}$ cells $[19,20]$. The GM-CSF receptor is a heterodimer of an $\alpha$-subunit which binds GM-CSF with low affinity and a signaling $\beta \mathrm{c}$ subunit which is shared with the IL-3 and IL-5 receptors [21]. The $\beta c$-subunit constitutively associates with Janus kinase 2 (JAK2) and is tyrosine phosphorylated by it resulting in an assembly of dodecameric signaling complex and initiation of signaling [22]. The effects of GM-CSF are mediated in a dose-dependent manner, by two $\beta$-chain residues: Ser 585 and Tyr577 [23]. At low concentrations of GM-CSF, as in normal healthy tissues, signaling occurs via Ser585 of the $\beta$ chain, which leads to activation of the PI-3 kinase pathway and results in myeloid cell survival. At high concentrations 
of GM-CSF, as at the site of inflammation, signaling via Ser585 is extinguished and signaling occurs exclusively via Tyr577 residue, which activates the Jak2/STAT5 pathway, Ras/mitogen-activated protein kinase pathway and PI-3 kinase pathway, resulting in cell survival, proliferation, and activation [23-26].

2.3. Action of GM-CSF. GM-CSF stimulates proliferation and activation of macrophages, monocytes, neutrophils, eosinophils, dendritic cells, and microglia $[1,27]$. However, since GM-CSF-deficient mice did not have a defect in myeloid cell development [28], a redundant role of GM-CSF in myeloid cell development and differentiation under steady state or homeostatic conditions is predicted. In addition to its function as a hematopoietic growth factor, GM-CSF is now recognized to have a variety of functions on mature hemopoietic cells. GM-CSF enhances proinflammatory cytokine production [29], antigen presentation [30, 31], and phagocytosis [32-35] and promotes leukocyte chemotaxis and adhesion [5, 36-38]. GM-CSF deficient mice have increased susceptibility to pulmonary [28,39-41] and intestinal infections [42] followed by systemic infection, indicating its importance in maintaining immune homeostasis particularly in the lung and intestines, which are constitutively exposed to pathogens.

2.3.1. Macrophages. GM-CSF stimulates the terminal differentiation of macrophages and the acquisition of normal immune functions via the transcription factor PU.1 [32]. GM-CSF also regulates phagocytosis of microbial pathogens by macrophages through the upregulation of pathogen associated molecular pattern (PAMP) receptors such as C-type lectins including mannose receptors or Dectin-1, scavenger receptors, integrins, or Fc $\gamma$ receptors via PU.1 $[24,32-34,43]$. Complement-dependent phagocytosis is also enhanced by GM-CSF to control microbial pathogens [44]. GM-CSF also upregulates the expression of TLR2, TLR4, or CD14 and boosts the production of proinflammatory cytokines such as TNF, IL-6, IL-12p70, IL-23, or IL-1 $\beta$ [24, $32,45,46]$, leading to polarization of macrophages to the M1- (classic-) like phenotype, thus, promoting Th1-Th17 responses $[29,47,48]$ and contributing to tissue destruction [49]. On the other hand, M-CSF polarizes macrophages to the M2- (alternative-) like phenotype, which produces antiinflammatory cytokines such as IL-10 and CC-chemokine ligand 2 (CCL2) and promotes tissue repair and remodeling [49]. GM-CSF also regulates many functions in macrophages including cell adhesion [32], pulmonary surfactant lipid and protein catabolism [32], and several important antimicrobial activities such as the production of reactive oxygen species (ROS) or expression of antimicrobial enzymes [40].

2.3.2. Dendritic Cells (DCs). GM-CSF positively regulates the development of migratory $\mathrm{CD} 103^{+} \mathrm{CD} 1 \mathrm{~b}^{+}$DCs [50] but negatively regulates the development of resident $\mathrm{CD}^{+}$ DCs [51]. GM-CSF also strongly induces the development of inflammatory monocyte-derived DCs (moDCs) in vitro [52]. However, it has not been well established whether GMCSF also regulates the development of moDCs in vivo. It was reported that the number of moDCs was increased in GM-CSF transgenic mice [53]. Furthermore, NF- $\kappa$ B1dependent GM-CSF production in CD4 T cells was reported to be required for the generation of moDCs in inflammatory arthritis and antigen-induced peritonitis mouse models. The number of moDCs was markedly reduced in draining lymph nodes from GM-CSF-/- mice with inflammatory arthritis or in the spleen of mice reconstituted with NF$\kappa \mathrm{B} 1-/-\mathrm{CD} 4 \mathrm{~T}$ cells in acute peritonitis, demonstrating that GM-CSF contributes to the differentiation of these cells during inflammation in vivo [54]. On the other hand, GMCSF was shown to be dispensable for the differentiation of moDCs, at least during acute infections, since the number of moDCs was not decreased in GM-CSF-/- mice or GMCSF receptor deficient mice during acute infections [55, 56]. These data indicate that although GM-CSF strongly regulates the production of moDCs in vitro and in vivo, there may be another GM-CSF-independent pathway for the development of moDCs [56]. Besides the regulation of DC development, GM-CSF also upregulates cross-presentation, bacterial uptake [53], or production of proinflammatory cytokines such as IL-6 or IL-23 in resident DCs [57].

2.3.3. Neutrophils. In mature neutrophils, GM-CSF upregulates the expression of the integrin CD11b, which increases cellular adhesion and tissue entry [36]. GM-CSF also upregulates the antimicrobial functions of neutrophils, such as phagocytosis or ROS production [58]. However, the expression of PU.1 in neutrophils of autoimmune pulmonary alveolar proteinosis patients was normal, indicating that GM-CSF is not involved in neutrophil differentiation [58].

2.3.4. B Cells. Among B cells, the innate-like B1 B cells reside predominantly in serosal cavities such as the pleural or peritoneal cavity. In response to microbial infection, Bla $B$ cells (a subset of $B 1 B$ cells) recognize bacteria via direct TLR-dependent pathogen recognition and differentiate into innate response activator (IRA) B cells, which produce GMCSF and also express the GM-CSF receptor $[59,60]$. GM-CSF acts on its receptor in an autocrine manner and induces IgM production from B cells $[59,61]$. Mixed chimeric mice with B cell-restricted GM-CSF deficiency showed high bacterial titer and morbidity after infection but did not show alveolar proteinosis [60], indicating that B cell-derived GM-CSF is necessary for protective IgM responses but dispensable for surfactant clearance by alveolar macrophages. These data indicate that the cellular source and location of GM-CSF is important.

\section{T Cell and GM-CSF}

Although GM-CSF is widely expressed in both stromal and hematopoietic cells, recent murine studies suggest that GMCSF from $\mathrm{CD}^{+} \mathrm{T}$ cells is essential in inflammatory mouse models such as experimental autoimmune encephalomyelitis (EAE), arthritis models such as collagen-induced arthritis (CIA) or SKG-arthritis, interstitial lung disease in SKG mice (SKG-ILD), peritonitis, or myocarditis [3, 4, 54, 57, 62-64]. 


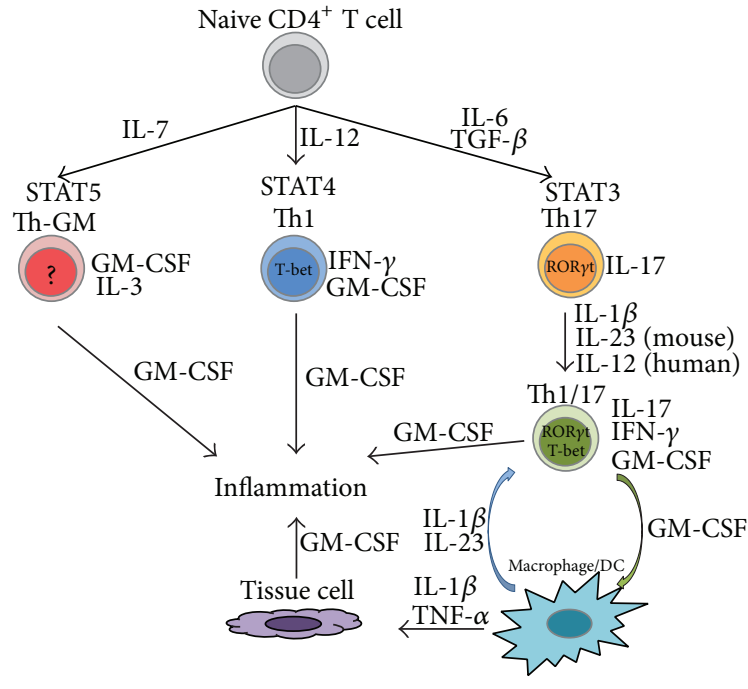

Figure 1: The differentiation of GM-CSF-producing $\mathrm{CD} 4^{+} \mathrm{T}$ cells and cytokine networks. Activated macrophages and dendritic cells (DCs) produce proinflammatory cytokines such as IL-23, IL-1 $\beta$, and IL-6, which can promote the differentiation of Th17 and Th1/17 cells, leading to more GM-CSF production from Th1/17 cells. Increased levels of GM-CSF upregulate further production of proinflammatory cytokines from macrophages/DCs, creating a positive feedback loop. Activated macrophages/DCs also produce proinflammatory cytokines, such as IL- $1 \beta$ and TNF $\alpha$, which stimulate the production of GM-CSF from resident tissue cells, including endothelial cells, epithelial cells, fibroblast, or chondrocytes.

Although GM-CSF is known as one of the Th17 cytokines, Th1 cells and Th2 cells also express GM-CSF [64-67]. Moreover, recent studies represent the existence of GM-CSF-producing Th cells distinct from Th1, Th2, or Th17 cells $[62,64]$ (Figure 1).

3.1. Th17 and Th1/17 Cells. Th17 cells have been shown to be strong inducers of tissue inflammation and autoimmune diseases. However, a number of studies determined that IL17 inhibition does not prevent but rather only ameliorates the development of $\operatorname{EAE}[3,4,68,69]$, CIA [70], SKG-arthritis, or SKG-ILD [63] and that neutralizing IL-17 is a rather unsatisfactory method for blocking Thl7 mediated diseases $[71,72]$. Recently, it was reported that "classical" Th17 cells, which mainly produce IL-17, are not pathogenic and that Th17 cells have high plasticity. As such, they instead differentiate into highly pathogenic cells, called Th1/17 cells [73]. Th1/17 cells are characterized by their ability to coproduce IL-17, IFN- $\gamma$, and GM-CSF and are identified by the coexpression of T-bet, ROR $\gamma \mathrm{t}$, and the chemokine receptors CXCR3 and CCR6 [9, 74-78]. Human Th1/17 cells also express CD161, a hallmark of Th17 progeny cells in humans that is induced by ROR $\gamma \mathrm{t}[76,79,80]$. Recent studies report that GM-CSF is critical for the pathogenicity of Th17 cells $[3,4]$ and the presence of Th1/17 cells was observed at the inflammatory site of inflammatory bowel disease (IBD), multiple sclerosis (MS), and juvenile idiopathic arthritis (JIA) $[76,78,81,82]$.
In mice, IL-23 and IL-1 $\beta$ induce the production of GMCSF in T cells whereas IL-12 suppresses its expression [3, $4,77,83$ ]. In contrast, in humans IL- $1 \beta$ renders Th17 cells sensitive to IL- 12 and both IL- $1 \beta$ and IL-12 promote the differentiation of Th1/17 cells $[9,75,81,84,85]$ (Figure 1). As described in Section 2.3, GM-CSF induces the differentiation of M1-like macrophages and upregulates the production of proinflammatory cytokines such as IL-6, IL-12, IL-23, or IL$1 \beta$ from antigen presenting cells (APCs) [57]. This results in further differentiation of Th17 and Th1/17 cells, thus creating a positive feedback loop [3,63].

Studies show that GM-CSF expression in $\mathrm{CD}^{+} \mathrm{T}$ cells is not regulated by T-bet $[3,4]$ and ROR-responsive elements are identified in the promoter of the gene encoding GMCSF [4]. Moreover, ectopic ROR $\gamma \mathrm{t}$ expression in $\mathrm{CD} 4^{+} \mathrm{T}$ cells results in GM-CSF production, indicating that GMCSF production in Th1/17 cells is induced by ROR $\gamma \mathrm{t}$ [4]. Conversely, ROR $\gamma \mathrm{t}$-deficient $\mathrm{CD} 4^{+} \mathrm{T}$ cells can produce GMCSF, indicating the existence of additional pathways to induce GM-CSF production in $\mathrm{CD}^{+} \mathrm{T}$ cells [3].

3.2. Th-GM Cells. Recently, it was reported that IL-2- or IL-7-activated STAT5 promotes the generation of GM-CSFproducing $\mathrm{CD}^{+}{ }^{+} \mathrm{T}$ cells with low or undetectable expression of T-bet, GATA-3, ROR $\gamma$ t transcripts. These cells represent a new distinct subset of Th cells, namely, Th-GM $[62,64]$. In humans, these Th-GM cells are identified as CCR $10^{+} \mathrm{CCR}^{+}{ }^{+} \mathrm{CXCR}^{-}{ }^{-} \mathrm{CCR} 6^{-}$Th cells [64]. It was reported that IL-7-activated STAT5 directly bound to promoter regions of the gene encoding GM-CSF [62]. The contribution of IL-7 has been implicated in autoimmune diseases such as multiple sclerosis or rheumatoid arthritis [86, 87], which also suggests the contribution of Th-GM cells in these diseases. High expression of IL-3, which is also involved in several autoimmune diseases [88-90], was also reported in Th-GM cells [62]. These cells were reported to be able to induce a more severe experimental autoimmune encephalomyelitis (EAE) than Th17 or Th1 cells $[62,64]$. It is possible that Th-GM cells provide GM-CSF to induce the expression of IL-23 from APCs and cooperate with Th1/17 or Th1 cells to exacerbate the development of inflammation.

3.3. Th1 Cells. Th1 cells are another source of GM-CSF [4]. It was reported that Thl cells also need GM-CSF to mediate inflammation in the central nervous system (CNS) [4]. However, the amount of GM-CSF produced by Th1 cells is found to be consistently lower than that produced by Th17 cells, particularly during in vitro culture [65].

3.4. Th2 Cells. Th2 cells also produce GM-CSF $[66,67]$. Although a positive correlation was found between GATA- $3^{+}$ cells and $\mathrm{GM}^{-\mathrm{CSF}^{+}}$cells in the nasal mucosa of patients with allergic rhinitis [91], there is no study to our knowledge that directly analyzes the role of GATA-3 in GM-CSF production. Further investigation is therefore needed to elucidate the precise mechanism of GM-CSF production from $\mathrm{CD} 4^{+} \mathrm{T}$ cells and their contribution to the development of autoimmune and inflammatory diseases. 


\section{GM-CSF in Autoimmune and Inflammatory Diseases}

4.1. GM-CSF in Central Nervous System. Multiple sclerosis (MS) is a chronic inflammatory disease of the central nervous system and is pathologically characterized by demyelination and subsequent axonal degeneration. Past studies have shown that $\mathrm{CD} 4^{+} \mathrm{T}$ cells play a critical role in the development of MS and experimental autoimmune encephalomyelitis (EAE), a widely used mouse model of MS. It has been widely believed that Th17 cells are the main encephalitogenic population in autoimmune inflammation [92]; however, IL-17 has been found to be dispensable for the development of EAE [4, 93]. On the other hand, GM-CSF deficiency or neutralization of GM-CSF has been reported to prevent the onset of $\mathrm{EAE}[94,95]$. The administration of recombinant GM-CSF worsened the disease in EAE [94] and elevated concentrations of GM-CSF have been reported in the cerebrospinal fluid but not in the serum of patients with relapsing-remitting or secondary progressive MS $[96,97]$.

Recent findings show that GM-CSF is secreted by CNSinfiltrating helper $\mathrm{T}$ cells and is essential for encephalitogenicity in EAE $[3,4,64]$. GM-CSF induces the proliferation and activation of microglial cells, which is required for the onset of EAE [95, 98]. Activated microglial cells produce highly neurotoxic substances such as ROS, nitrogen species, glutamate, and TNF- $\alpha$ [99-102]. Furthermore, GM-CSFproducing $\mathrm{CD}^{+} \mathrm{T}$ cells induce the differentiation of neurotoxic M1-like phenotype of microglia [103] and upregulate the production of proinflammatory mediators such as IL- $1 \beta$, IL6 , and TNF $\alpha$, which contribute to myelin sheath damage, via upregulation of TLR and CD14 expression [45].

Studies also show that GM-CSF is required for recruitment of peripheral myeloid cells that contribute to bloodbrain barrier (BBB) and blood-spinal cord barrier (BSCB) disruption and demyelization into the CNS $[104,105]$. As we described in Section 3.1, GM-CSF induces the polarization of the M1-like macrophage phenotype and exacerbates the positive feedback loop of Th17 and Th1/17 differentiation. Indeed, an increased M1/M2 profile ratio of monocyte/macrophages in the blood as well as in the CNS favors relapsing EAE and a reduced $\mathrm{M} 1 / \mathrm{M} 2$ ratio promotes an attenuated manifestation of the disease [106]. The ability of CNS-invading myeloid cells to respond to $\mathrm{CD} 4^{+} \mathrm{T}$ cell-derived GM-CSF was shown to be vital for the development of EAE [4].

Taken together, CNS-infiltrating $\mathrm{CD}^{+} \mathrm{T}$ cells initially activate microglia and induce production of proinflammatory cytokines, which contribute to myelin sheath damage [95]. This initial neuroinflammation results in BBB destruction and leukocyte infiltration into the CNS parenchyma, followed by restimulation of $\mathrm{T}$ cells by resident and infiltrating APCs [107], leading to further APC activation.

These reports indicate that GM-CSF plays a central role in MS and indicate that the inhibition of GM-CSF will be a useful therapeutic strategy for MS. MOR103, a fully human monoclonal antibody that binds human GM-CSF, is currently being tested in a phase Ib trial for MS [108] (Table 1). The result of this and future trials are highly anticipated.
4.2. GM-CSF in Arthritis. Rheumatoid arthritis (RA) is a systemic chronic autoimmune disease characterized by persistent and erosive inflammatory polyarthritis. Recent studies indicate that GM-CSF plays a central role in the pathogenesis of RA as in MS, by activating or promoting differentiation and survival of macrophages and neutrophils $[109,110]$. The concentrations of GM-CSF were elevated in the synovial fluid and plasma of RA patients [111, 112]. A case report showed that the administration of recombinant GM-CSF exacerbated the disease activity of RA [113]. The frequency of GM-CSFproducing Th cells was significantly increased in synovial fluid cells compared to peripheral blood mononuclear cells (PBMCs) in patients with juvenile idiopathic arthritis (JIA) and correlated with erythrocyte sedimentation rate (ESR) levels [81, 114]. Synovial GM-CSF-producing T cells were predominantly CD161 positive and coexpressed IFN- $\gamma$ but not IL-17 [81], indicating that these cells are Th1/17 cells. Alternatively, human synovial fibroblasts and chondrocytes were also reported to produce GM-CSF in response to IL-1 and TNF stimulation $[115,116]$.

The contribution of GM-CSF in the development of arthritis was also reported in several mouse models of arthritis. In the collagen-induced arthritis (CIA) model, GMCSF deficient mice failed to develop arthritis [117], and the administration of anti-GM-CSF neutralizing antibodies ameliorated existing disease, prevented disease progression, and reduced the concentrations of TNF and IL-1 in the joints of treated mice [118]. On the other hand, GM-CSF administration exacerbated arthritis in CIA [119].

In SKG mice, another model of autoimmune arthritis, GM-CSF, upregulated proinflammatory cytokine production such as IL- $1 \beta$ or IL- 6 from macrophages in a dose dependent manner $[63,120]$. This in turn induced further differentiation and expansion of IL-17-producing and GM-CSF-producing $\mathrm{CD}^{+}{ }^{+} \mathrm{T}$ cells [63]. The progression of arthritis in SKG mice was inhibited by the neutralization of GM-CSF and slightly by the neutralization of IL-17A [63], indicating that GM-CSF plays a more critical role than IL-17A in SKG arthritis.

Mavrilimumab, a fully human anti-GM-CSF receptor $\alpha$ antibody, is currently being developed and a phase II study in RA patients reported significant efficacy with no serious adverse events such as pulmonary alveolar proteinosis [121]. In this study of patients with active RA despite methotrexate treatment, $55.7 \%$ of all participants treated with mavrilimumab met the primary end point of achieving $\geq 1.2$ decrease from baseline in the disease activity score (DAS28-CRP) at week 12. At the highest dose of mavrilimumab (100 mg), $66.7 \%$ of subjects met the primary end point versus only $34.7 \%$ of the subjects in the placebo group [121].

MOR103, which is also being tested for MS, has shown preliminary evidence of efficacy in a phase Ib/IIa trial for patients with active RA [122]. Subjects receiving higher doses of MOR103 (1.0 and $1.5 \mathrm{mg} / \mathrm{kg}$ ) showed significant improvement in DAS28 scores and joint counts and significantly higher European league against rheumatism response rates than subjects receiving placebo [122]. Both mavrilimumab and MOR103 showed rapid treatment responses and provided evidence of clinical efficacy that support further clinical investigation. Table 2 shows the results of clinical trials with 
TABLE 1: Clinical trials targeting GM-CSF.

\begin{tabular}{lccccl}
\hline Target & Drug & Type & Indication & Phase & Status \\
\hline GM-CSFR & $\begin{array}{c}\text { Mavrilimumab } \\
\text { (CAM-3001) }\end{array}$ & mAb & RA & II & Completed \\
GM-CSF & MOR103 & mAb & RA & Ib/IIa & Completed \\
& Namilumab & mAb & RA & Ib & Completed, not published yet \\
GM-CSF & (MT203) & Plaque psoriasis & I & Completed, not published yet \\
& KB003 & Humaneered & RA & II & On-going \\
GM-CSF & mAb & Asthma & II & Completed, not published yet \\
GM-CSF & MORAb-022 & mAb & RA & I & On-going \\
\hline
\end{tabular}

GM-CSFR: GM-CSF receptor; mAb: monoclonal antibody; RA: rheumatoid arthritis; MS: multiple sclerosis.

TABLE 2: Effects of GM-CSF inhibitors in RA.

\begin{tabular}{|c|c|c|c|}
\hline Drug & Regimen & Patients & Efficacy (versus placebo) \\
\hline $\begin{array}{l}\text { Mavrilimumab } \\
\text { (CAM-3001) } \\
\text { Phase II } \\
{[121]}\end{array}$ & $\begin{array}{l}10,30,50 \text {, or } 100 \mathrm{mg}, \mathrm{SC} \\
\text { every other week }\end{array}$ & $\begin{array}{l}N=233 \\
\text { On stable MTX }\end{array}$ & $\begin{array}{l}\text { DAS28 change: }-1.2 \text { at week } 12 \\
41.0 \%, 61.0 \%, 53.8 \% \text {, and } 66.7 \% \text { versus } 34.7 \% \\
(P=0.543,0.011,0.071 \text {, and } 0.001) \\
\text { ACR at week } 12100 \mathrm{mg} \text { dose versus Placebo } \\
\text { ACR20: } 69.2 \% \text { versus } 40.0 \%(P=0.005) \\
\text { ACR50: } 30.8 \% \text { versus } 12.0 \%(P=0.021) \\
\text { ACR70: } 17.9 \% \text { versus } 4.0 \%(P=0.030)\end{array}$ \\
\hline $\begin{array}{l}\text { MOR103 } \\
\text { Phase Ib/IIa } \\
{[122]}\end{array}$ & $\begin{array}{l}0.3,1.0 \text {, or } 1.5 \mathrm{mg} / \mathrm{kg}, \mathrm{IV} \\
\text { once a week for } 4 \text { weeks, } \\
\text { with follow-up to } 16 \text { weeks }\end{array}$ & $N=96$ & $\begin{array}{l}\text { Significant differences in DAS28 change between placebo and MOR-103: } \\
\text { None, weeks } 4 \text { through } 10 \text {, weeks } 4 \text { through } 6 \\
\text { ACR at week } 4,1.0 \mathrm{mg} / \mathrm{kg} \text { versus placebo } \\
\text { ACR20: } 68.2 \% \text { versus } 7.4 \%(P<0.0001) \\
\text { ACR50: } 22.7 \% \text { versus } 3.7 \%(\mathrm{~ns}) \\
\text { ACR70: } 4.5 \% \text { versus } 0.0 \%(\mathrm{~ns})\end{array}$ \\
\hline
\end{tabular}

SC: subcutaneous injection; IV: intravenous injection; MTX: methotrexate; DAS28: 28-joint disease activity score; ACR20: American College of Rheumatology 20\% response rate; ACR50: American College of Rheumatology 50\% response rate; ACR70: American College of Rheumatology $70 \%$ response rate.

mavrilimumab and MOR103. A list of ongoing/completed clinical trials targeting GM-CSF or its receptor is presented in Table 1, with more information available at ClinicalTrials.gov.

\subsection{GM-CSF in Lung Disease}

4.3.1. Pulmonary Alveolar Proteinosis. Pulmonary alveolar proteinosis (PAP) is a rare syndrome characterized by the accumulation of surfactant in pulmonary alveoli resulting in varying degrees of respiratory insufficiency and myeloid cell dysfunction leading to increased risk of infection $[123,124]$. Several clinical forms of PAP have been identified including autoimmune PAP caused by GM-CSF autoantibodies, hereditary PAP caused by GM-CSF receptor mutations, and secondary PAP associated with various underlying clinical disorders which is presumed to cause this syndrome by reducing alveolar macrophage numbers or function [125]. It is also reported that GM-CSF deficient mice develop abnormal lung histology that is virtually indistinguishable from human PAP [126].

Pulmonary surfactant is tightly regulated by balanced production, secretion, reuptake, and catabolism within alveoli. GM-CSF regulates surfactant catabolism in alveolar macrophages via PU.1 but does not regulate surfactant endocytosis or uptake and catabolism of surfactant by alveolar epithelial cells type II (AEC-II) [32, 127]. GM-CSF is also required to stimulate numerous immune functions and terminal differentiation of alveolar macrophages [32] and induction of IgM production from B cells $[60,61]$. Therefore, GMCSF deficient mice have high susceptibility to pulmonary infections [28, 39-41] accompanied by systemic infections. Based on the pathogenesis of PAP, several new therapeutic approaches for treating autoimmune PAP targeting GM-CSF are in clinical trials, including plasmapheresis [128], GM-CSF administration $[129,130]$, and rituximab $[131,132]$.

4.3.2. Interstitial Lung Disease. The mechanism of pulmonary fibrosis in interstitial lung disease (ILD) has been studied using Idiopathic pulmonary fibrosis (IPF) or a bleomycininduced mouse model of pulmonary fibrosis. Pulmonary fibrosis in IPF is considered to be inflammation-independent and mainly initiated by TGF- $\beta$ produced by damaged epithelial cells. In fact, anti-inflammatory therapies have little benefit in IPF [133-135]. However, neutrophils, which produce ROS, MMPs, neutrophil elastase, or myeloperoxidase and cause lung parenchymal and stromal cell injury [136138] or Th2 cytokines such as IL-4 or IL-13, which induce fibroblast differentiation or extracellular matrix synthesis $[139,140]$, have been reported to contribute to lung fibrosis to some extent. Additionally, GM-CSF was reported to take 
part in the progress of pulmonary fibrosis. It was reported that $\mathrm{TNF} \alpha$-induced endothelin-1 (ET-1) upregulates GMCSF production from airway smooth muscle cells (ASMCs) [141] and that GM-CSF was increased in the bronchoalveolar lavage fluid (BALF) of patients with pulmonary fibrosis [142, 143]. GM-CSF stimulates macrophages to release profibrotic cytokines and also induces fibrosis by direct stimulation of airway smooth muscle cells $[144,145]$. In fact, overexpression of GM-CSF in the lungs led to severe neutrophil, eosinophil, and macrophage infiltration and fibrotic reactions [145-147].

In contrast with idiopathic pulmonary fibrosis (IPF), connective tissue disease-associated ILD (CTD-ILD) is often characterized by a clearer response to immunosuppression, indicating that autoimmune/inflammatory mechanisms play a more significant and central role in the pathogenesis of CTD-ILD [148, 149]. SKG mice, a model of autoimmune arthritis, were reported to develop chronic-progressive interstitial lung disease (ILD) that histologically resembles CTDILD $[63,150,151]$. Recently, it was reported that ILD in this mouse was characterized by massive infiltration of Th17 cells, GM-CSF-producing CD $4^{+} \mathrm{T}$ cells, and $\mathrm{CD}_{11 \mathrm{~b}}{ }^{+} \mathrm{Grl}^{+}$ neutrophils with fibrosis [63]. Naive SKG T cells were skewed to differentiate into GM-CSF-producing cells. Furthermore, GM-CSF secreted by T cells enhanced IL- 6 and IL- $1 \beta$ production by macrophages, which in turn enhanced differentiation of IL-17A and/or GM-CSF-producing T cells and infiltration of neutrophils into the lungs [63]. Neutralization of GM-CSF completely blocked the development of this ILD, whereas neutralization of IL-17A did not, showing that GM-CSF not IL-17A is critical for the development of ILD in SKG mice [63]. Importantly, neutralization of GM-CSF ameliorated ILD in SKG mice even after the onset of ILD [63], suggesting that GM-CSF inhibition is a useful therapeutic strategy for CTDILD. Mavrilimumab, a fully human anti-GM-CSF receptor $\alpha$ antibody and MOR103, a fully human monoclonal anti-GMCSF antibody, are undergoing clinical trials in RA patients $[121,122]$. Further studies and future trials targeting GM-CSF are awaited with interest.

4.4. GM-CSF in Intestine. Recent developments suggest that the development of Crohn's disease (CD) is caused by a mucosal innate immunodeficiency with a variety of genetic defects [152] and a dysfunction of granulocytes, macrophages, and intestinal epithelial cells $[153,154]$. In the intestine, GMCSF contributes to gut barrier function and resistance to bacterial translocation by promoting the recruitment and activation of monocytes/macrophages, neutrophils, and DCs. This is accompanied by differentiation of Th1 and Th17 cells. GM-CSF also promotes tissue repair via increased intestinal epithelial cell proliferation and increased macrophages as effectors of wound healing [155-157]. However, in CD patients, the inherent defects in the mucosal barrier increase the translocation of pathogens to the bowel tissue [152]. Moreover, increased levels of GM-CSF autoantibodies have been reported in patients with ileal/ileocolonic CD, compared with those with colon involvement only, ulcerative colitis (UC) patients, or healthy controls. The high levels of GM-CSF antibodies directly correlated with disease activity and inversely correlated with neutrophil phagocytic activity [158]. Increased GM-CSF autoantibodies affect mucosal integrity, bacterial killing and neutrophil migration, proliferation, and survival [156]. GM-CSF deficient mice also developed a more severe intestinal and systemic infection after enteric infection [42] and were more susceptible to acute dextran sodium sulfate- (DSS-) induced colitis [159]. Both severity of infection and colitis were largely prevented by GM-CSF administration $[160,161]$. On the other hand, GM-CSF overexpression in the stomach leads to autoimmune gastritis [162] and experimental peritonitis or intraperitoneal LPS exposure in GM-CSF deficient mice resulted in blunted proinflammatory responses and mortality [163]. The expression of GM-CSF at the mRNA level increases from the stomach distally down through the colon, indicating that gastrointestinal expression of GM-CSF expression parallels bacterial localization [164]. These data indicate that the threshold of GM-CSF levels between inflammation and immune homeostasis can vary with tissue location or organs.

These findings indicate that administration of GM-CSF could be beneficial for the treatment for CD patients. Initial reports indicated that the administration of GM-CSF in CD patients with moderate to severe disease activity had a high rate of clinical response and remission with minimal adverse effects $[165,166]$. Moreover, a randomized phase II clinical trial demonstrated that GM-CSF was significantly more effective than placebo in obtaining a corticosteroidfree clinical remission [167]. Conversely, a recent large randomized trial found that it was no more effective than placebo for induction of clinical remission or improvement in active CD [168]. CD patients are known to have substantial heterogeneity in pathogenic mechanisms and so GM-CSF as a therapy may only be appropriate for a subgroup of patients. Additionally, it is also important to verify the efficacy of GMCSF not only for the induction of remission but also for the maintenance of remission. Therefore, further studies are needed to elucidate the efficacy of GM-CSF as a treatment as well as the appropriate patient character or phase of disease to apply GM-CSF administration as a therapy.

4.5. GM-CSF in Allergic Disease. GM-CSF also was reported to take part in Th2 response in allergic airway inflammation via activation of DCs [169-171]. In mouse models of asthma, allergen-exposed epithelial cells release GM-CSF which activates DCs and also prolongs eosinophil survival $[170,172]$. Consequently, GM-CSF neutralization reduced allergic hyperresponsiveness in mice models [169, 170, 172]. KB003, a "humaneered" anti-GM-CSF antibody, is tested in a phase II trial for severe asthma (Table 1). The result of this trial is awaited.

\section{Conclusion}

GM-CSF plays pivotal roles not only in maintaining immune homeostasis but also in exacerbating inflammatory reactions. Recent findings indicate that GM-CSF inhibition will be an attractive therapeutic strategy for many autoimmune and inflammatory diseases. Studies also indicate that it is 
necessary to monitor possible side effects such as PAP or CD, although GM-CSF inhibition has no demonstrated serious adverse reactions so far, which is indicative of its wide therapeutic index $[63,173,174]$. Further studies are necessary to identify the molecular mechanisms that regulate GM-CSF production and the role of GM-CSF in the development of inflammatory diseases to devise preventive or curative strategies for autoimmune and inflammatory diseases.

\section{Conflict of Interests}

The authors declare that there is no conflict of interests regarding the publication of this paper.

\section{References}

[1] A. W. Burgess, J. Camakaris, and D. Metcalf, "Purification and properties of colony stimulating factor from mouse lung conditioned medium," The Journal of Biological Chemistry, vol. 252, no. 6, pp. 1998-2003, 1977.

[2] J. A. Hamilton and A. Achuthan, "Colony stimulating factors and myeloid cell biology in health and disease," Trends in Immunology, vol. 34, no. 2, pp. 81-89, 2013.

[3] M. El-Behi, B. Ciric, H. Dai et al., "The encephalitogenicity of $\mathrm{T}_{H} 17$ cells is dependent on IL-1- and IL-23-induced production of the cytokine GM-CSF," Nature Immunology, vol. 12, no. 6, pp. 568-575, 2011.

[4] L. Codarri, G. Gyülvészii, V. Tosevski et al., "ROR $\gamma 3$ t drives production of the cytokine GM-CSF in helper T cells, which is essential for the effector phase of autoimmune neuroinflammation," Nature Immunology, vol. 12, no. 6, pp. 560-567, 2011.

[5] J. A. Hamilton, "GM-CSF in inflammation and autoimmunity," Trends in Immunology, vol. 23, no. 8, pp. 403-408, 2002.

[6] A. J. Fleetwood, A. D. Cook, and J. A. Hamilton, "Functions of granulocyte-macrophage colony-stimulating factor," Critical Reviews in Immunology, vol. 25, no. 5, pp. 405-428, 2005.

[7] H. Fukuzawa, M. Sawada, T. Kayahara et al., "Identification of GM-CSF in Paneth cells using single-cell RT-PCR," Biochemical and Biophysical Research Communications, vol. 312, no. 4, pp. 897-902, 2003.

[8] J. R. Lukens, M. J. Barr, D. D. Chaplin, H. Chi, and T.D. Kanneganti, "Inflammasome-derived IL-lbeta regulates the production of GM-CSF by CD4(+) T cells and gammadelta T cells," Journal of Immunology, vol. 188, no. 7, pp. 3107-3115, 2012.

[9] T. Duhen and D. J. Campbell, "IL-1 $\beta$ promotes the differentiation of polyfunctional human $\mathrm{CCR}^{+} \mathrm{CXCR}^{+}$Th1/17 cells that are specific for pathogenic and commensal microbes," The Journal of Immunology, vol. 193, no. 1, pp. 120-129, 2014.

[10] H. Quill, A. Gaur, and R. P. Phipps, "Prostaglandin E2dependent induction of granulocyte-macrophage colonystimulating factor secretion by cloned murine helper T cells," Journal of Immunology, vol. 142, no. 3, pp. 813-818, 1989.

[11] C. Shang, J. Attema, D. Cakouros, P. N. Cockerill, and M. F. Shannon, "Nuclear factor of activated $\mathrm{T}$ cells contributes to the function of the CD28 response region of the granulocyte macrophage-colony stimulating factor promoter," International Immunology, vol. 11, no. 12, pp. 1945-1956, 1999.

[12] B. V. Johnson, A. G. Bert, G. R. Ryan, A. Condina, and P. N. Cockerill, "Granulocyte-macrophage colony-stimulating factor enhancer activation requires cooperation between NFAT and
AP-1 elements and is associated with extensive nucleosome reorganization," Molecular and Cellular Biology, vol. 24, no. 18, pp. 7914-7930, 2004.

[13] H. Ozawa, S. Aiba, S. Nakagawa, and H. Tagami, "Interferongamma and interleukin-10 inhibit antigen presentation by Langerhans cells for $\mathrm{T}$ helper type 1 cells by suppressing their CD80 (B7-1) expression," European Journal of Immunology, vol. 26, no. 3, pp. 648-652, 1996.

[14] J. H. Jansen, G. H. M. Wientjens, W. E. Fibbe, R. Willemze, and H. C. Kluin-Nelemans, "Inhibition of human macrophage colony formation by interleukin 4," The Journal of Experimental Medicine, vol. 170, no. 2, pp. 577-582, 1989.

[15] K. Sagawa, M. Mochizuki, S. Sugita, K. Nagai, T. Sudo, and K. Itoh, "Suppression by IL-10 and IL-4 of cytokine production induced by two-way autologous mixed lymphocyte reaction," Cytokine, vol. 8, pp. 501-506, 1996.

[16] A. Tsuboi, E. S. Masuda, Y. Naito, H. Tokumitsu, K.-I. Arai, and N. Arai, "Calcineurin potentiates activation of the granulocytemacrophage colony-stimulating factor gene in T cells: involvement of the conserved lymphokine element 0," Molecular Biology of the Cell, vol. 5, no. 1, pp. 119-128, 1994.

[17] S. M. Hatfield and N. W. Roehm, "Cyclosporine and FK506 inhibition of murine mast cell cytokine production," Journal of Pharmacology and Experimental Therapeutics, vol. 260, no. 2, pp. 680-688, 1992.

[18] I. M. Adcock and G. Caramori, "Cross-talk between proinflammatory transcription factors and glucocorticoids," Immunology and Cell Biology, vol. 79, no. 4, pp. 376-384, 2001.

[19] F. Colotta, F. Bussolino, N. Polentarutti et al., "Differential expression of the common $\beta$ and specific $\alpha$ chains of the receptors for GM-CSF, IL-3, and IL-5 in endothelial cells," Experimental Cell Research, vol. 206, no. 2, pp. 311-317, 1993.

[20] M. Roasa, S. Gordon, and P. R. Taylor, "Characterisation of the expression and function of the GM-CSF receptor alpha-chain in mice," European Journal of Immunology, vol. 37, no. 9, pp. 25182528, 2007.

[21] M. Martinez-Moczygemba and D. P. Huston, "Biology of common beta receptor-signaling cytokines: IL-3, IL-5, and GMCSF," Journal of Allergy and Clinical Immunology, vol. 112, no. 4, pp. 653-666, 2003.

[22] G. Hansen, T. R. Hercus, B. J. McClure et al., "The structure of the GM-CSF receptor complex reveals a distinct mode of cytokine receptor activation," Cell, vol. 134, no. 3, pp. 496-507, 2008.

[23] M. A. Guthridge, E. F. Barry, F. A. Felquer et al., "The phosphoserine-585-dependent pathway of the GM-CSF/IL3/IL-5 receptors mediates hematopoietic cell survival through activation of NF- $\kappa \mathrm{B}$ and induction of bcl-2," Blood, vol. 103, no. 3, pp. 820-827, 2004.

[24] P.-Y. Berclaz, B. Carey, M.-D. Fillipi et al., "GM-CSF regulates a PU.1-dependent transcriptional program determining the pulmonary response to LPS," American Journal of Respiratory Cell and Molecular Biology, vol. 36, no. 1, pp. 114-121, 2007.

[25] T. R. Hercus, U. Dhagat, W. L. T. Kan et al., "Signalling by the $\beta \mathrm{c}$ family of cytokines," Cytokine and Growth Factor Reviews, vol. 24, no. 3, pp. 189-201, 2013.

[26] M. A. Guthridge, J. A. Powell, E. F. Barry et al., "Growth factor pleiotropy is controlled by a receptor Tyr/Ser motif that acts as a binary switch," The EMBO Journal, vol. 25, no. 3, pp. 479-489, 2006. 
[27] J. A. Hamilton, "Colony-stimulating factors in inflammation and autoimmunity," Nature Reviews Immunology, vol. 8, no. 7, pp. 533-544, 2008.

[28] E. Stanley, G. J. Lieschke, D. Grail et al., "Granulocyte/macrophage colony-stimulating factor-deficient mice show no major perturbation of hematopoiesis but develop a characteristic pulmonary pathology," Proceedings of the National Academy of Sciences of the United States of America, vol. 91, no. 12, pp. 55925596, 1994.

[29] A. J. Fleetwood, T. Lawrence, J. A. Hamilton, and A. D. Cook, "Granulocyte-macrophage colony-stimulating factor (CSF) and macrophage CSF-dependent macrophage phenotypes display differences in cytokine profiles and transcription factor activities: implications for CSF blockade in inflammation," Journal of Immunology, vol. 178, no. 8, pp. 5245-5252, 2007.

[30] P. J. Morrissey, L. Bressler, L. S. Park, A. Alpert, and S. Gillis, "Granulocyte-macrophage colony-stimulating factor augments the primary antibody response by enhancing the function of antigen-presenting cells," Journal of Immunology, vol. 139, no. 4, pp. 1113-1119, 1987.

[31] J. M. Alvaro-Garcia, N. J. Zvaifler, and G. S. Firestein, "Cytokines in chronic inflammatory arthritis. IV. Granulocyte/macrophage colony-stimulating factor-mediated induction of class II MHC antigen on human monocytes: a possible role in rheumatoid arthritis," The Journal of Experimental Medicine, vol. 170, no. 3, pp. 865-875, 1989.

[32] Y. Shibata, P.-Y. Berclaz, Z. C. Chroneos, M. Yoshida, J. A. Whitsett, and B. C. Trapnell, "GM-CSF regulates alveolar macrophage differentiation and innate immunity in the lung through PU.1," Immunity, vol. 15, no. 4, pp. 557-567, 2001.

[33] P.-Y. Berclaz, Y. Shibata, J. A. Whitsett, and B. C. Trapnell, "GMCSF, via PU.1, regulates alveolar macrophage $\mathrm{F} c \gamma \mathrm{R}$-mediated phagocytosis and the IL-18/IFN- $\gamma$-mediated molecular connection between innate and adaptive immunity in the lung," Blood, vol. 100, no. 12, pp. 4193-4200, 2002.

[34] P.-Y. Berclaz, Z. Zsengellér, Y. Shibata et al., "Endocytic internalization of adenovirus, nonspecific phagocytosis, and cytoskeletal organization are coordinately regulated in alveolar macrophages by GM-CSF and PU.1," Journal of Immunology, vol. 169, no. 11, pp. 6332-6342, 2002.

[35] A. D. Cook, E. L. Braine, and J. A. Hamilton, "Stimulusdependent requirement for granulocyte-macrophage colonystimulating factor in inflammation," Journal of Immunology, vol. 173, no. 7, pp. 4643-4651, 2004.

[36] T. Sakagami, K. Uchida, T. Suzuki et al., "Human GM-CSF autoantibodies and reproduction of pulmonary alveolar proteinosis," The New England Journal of Medicine, vol. 361, no. 27, pp. 2679-2681, 2009.

[37] J. Gomez-Cambronero, J. Horn, C. C. Paul, and M. A. Baumann, "Granulocyte-macrophage colony-stimulating factor is a chemoattractant cytokine for human neutrophils: involvement of the ribosomal p70 S6 kinase signaling pathway," Journal of Immunology, vol. 171, no. 12, pp. 6846-6855, 2003.

[38] D. Metcalf, "Hematopoietic cytokines," Blood, vol. 111, no. 2, pp. 485-491, 2008.

[39] R. Paine III, A. M. Preston, S. Wilcoxen et al., "Granulocytemacrophage colony-stimulating factor in the innate immune response to Pneumocystis carinii pneumonia in mice," The Journal of Immunology, vol. 164, no. 5, pp. 2602-2609, 2000.

[40] A. M. LeVine, J. A. Reed, K. E. Kurak, E. Cianciolo, and J. A. Whitsett, "GM-CSF-deficient mice are susceptible to pulmonary group B streptococcal infection," Journal of Clinical Investigation, vol. 103, no. 4, pp. 563-569, 1999.

[41] J. F. Seymour, G. J. Lieschke, D. Grail, C. Quilici, G. Hodgson, and A. R. Dunn, "Mice lacking both granulocyte colonystimulating factor (CSF) and granulocyte-macrophage CSF have impaired reproductive capacity, perturbed neonatal granulopoiesis. Lung disease, amyloidosis, and reduced long-term survival," Blood, vol. 90, no. 8, pp. 3037-3049, 1997.

[42] Y. Hirata, L. Egea, S. M. Dann, L. Eckmann, and M. F. Kagnoff, "GM-CSF-facilitated dendritic cell recruitment and survival govern the intestinal mucosal response to a mouse enteric bacterial pathogen," Cell Host and Microbe, vol. 7, no. 2, pp. 151163,2010 .

[43] C. H. Serezani, S. Kane, L. Collins, M. Morato-Marques, J. J. Osterholzer, and M. Peters-Golden, "Macrophage dectin-1 expression is controlled by leukotriene B4 via a GM-CSF/PU.1 axis," Journal of Immunology, vol. 189, no. 2, pp. 906-915, 2012.

[44] H. L. Collins and G. J. Bancroft, "Cytokine enhancement of complement-dependent phagocytosis by macrophages: synergy of tumor necrosis factor- $\alpha$ and granulocyte-macrophage colony-stimulating factor for phagocytosis of Cryptococcus neoformans," European Journal of Immunology, vol. 22, no. 6, pp. 1447-1454, 1992.

[45] B. Parajuli, Y. Sonobe, J. Kawanokuchi et al., "GM-CSF increases LPS-induced production of proinflammatory mediators via upregulation of TLR4 and CD14 in murine microglia," Journal of Neuroinflammation, vol. 9, article 268, 2012.

[46] C. A. Sorgi, S. Rose, N. Court et al., "GM-CSF priming drives bone marrow-derived macrophages to a pro-inflammatory pattern and downmodulates $\mathrm{PGE}_{2}$ in response to TLR2 ligands," PLoS ONE, vol. 7, no. 7, Article ID e40523, 2012.

[47] T. Krausgruber, K. Blazek, T. Smallie et al., "IRF5 promotes inflammatory macrophage polarization and T H1-TH17 responses," Nature Immunology, vol. 12, no. 3, pp. 231-238, 2011.

[48] F. A. W. Verreck, T. De Boer, D. M. L. Langenberg et al., "Human IL-23-producing type 1 macrophages promote but IL-10-producing type 2 macrophages subvert immunity to (myco)bacteria," Proceedings of the National Academy of Sciences of the United States of America, vol. 101, no. 13, pp. 45604565, 2004.

[49] D. Zhou, C. Huang, Z. Lin et al., "Macrophage polarization and function with emphasis on the evolving roles of coordinated regulation of cellular signaling pathways," Cellular Signalling, vol. 26, no. 2, pp. 192-197, 2014.

[50] I. L. King, M. A. Kroenke, and B. M. Segal, "GM-CSF-dependent, $\mathrm{CD}_{103}{ }^{+}$dermal dendritic cells play a critical role in Th effector cell differentiation after subcutaneous immunization," Journal of Experimental Medicine, vol. 207, no. 5, pp. 953-961, 2010.

[51] E. Daro, B. Pulendran, K. Brasel et al., "Polyethylene glycolmodified GM-CSF expands $\mathrm{CD}_{11} \mathrm{~b}^{\text {high }} \mathrm{CD} 11 \mathrm{c}^{\text {high }}$ but not $\mathrm{CD}_{11 b^{\text {low }}} \mathrm{CD} 11 \mathrm{c}^{\text {high }}$ murine dendritic cells in vivo: a comparative analysis with Flt3 ligand," The Journal of Immunology, vol. 165, no. 1, pp. 49-58, 2000.

[52] C. Caux, B. Vanbervliet, C. Massacrier et al., "CD34+ hematopoietic progenitors from human cord blood differentiate along two independent dendritic cell pathways in response to GM-CSF+TNF $\alpha$," Journal of Experimental Medicine, vol. 184, no. 2, pp. 695-706, 1996.

[53] Y. Zhan, E. M. Carrington, A. van Nieuwenhuijze et al., "GM-CSF increases cross-presentation and CD103 expression 
by mouse $\mathrm{CD}^{+}$spleen dendritic cells," European Journal of Immunology, vol. 41, no. 9, pp. 2585-2595, 2011.

[54] I. K. Campbell, A. van Nieuwenhuijze, E. Segura et al., "Differentiation of inflammatory dendritic cells is mediated by NF-kappaB1-dependent GM-CSF production in CD4 T cells," Journal of Immunology, vol. 186, no. 9, pp. 5468-5477, 2011.

[55] M. Greter, J. Helft, A. Chow et al., "GM-CSF controls nonlymphoid tissue dendritic cell homeostasis but is dispensable for the differentiation of inflammatory dendritic cells," Immunity, vol. 36, no. 6, pp. 1031-1046, 2012.

[56] Y. Zhan, Y. Xu, and A. M. Lew, "The regulation of the development and function of dendritic cell subsets by GM-CSF: more than a hematopoietic growth factor," Molecular Immunology, vol. 52, no. 1, pp. 30-37, 2012.

[57] I. Sonderegger, G. Iezzi, R. Maier, N. Schmitz, M. Kurrer, and M. Kopf, "GM-CSF mediates autoimmunity by enhancing IL6-dependent Th17 cell development and survival," Journal of Experimental Medicine, vol. 205, no. 10, pp. 2281-2294, 2008.

[58] K. Uchida, D. C. Beck, T. Yamamoto et al., "GM-CSF autoantibodies and neutrophil dysfunction in pulmonary alveolar proteinosis," The New England Journal of Medicine, vol. 356, no. 6, pp. 567-579, 2007.

[59] P. J. Rauch, A. Chudnovskiy, C. S. Robbins et al., "Innate response activator B cells protect against microbial sepsis," Science, vol. 335, no. 6068, pp. 597-601, 2012.

[60] G. F. Weber, B. G. Chousterman, I. Hilgendorf et al., "Pleural innate response activator $\mathrm{B}$ cells protect against pneumonia via a GM-CSF-IgM axis," The Journal of Experimental Medicine, vol. 211, no. 6, pp. 1243-1256, 2014.

[61] C. M. Snapper, M. A. Moorman, F. R. Rosas, M. R. Kehry, C. R. Maliszewski, and J. J. Mond, "IL-3 and granulocyte-macrophage colony-stimulating factor strongly induce Ig secretion by sortpurified murine B cell activated through the membrane Ig, but not the CD40, signaling pathway," Journal of Immunology, vol. 154, no. 11, pp. 5842-5850, 1995.

[62] W. Sheng, F. Yang, Y. Zhou et al., "STAT5 programs a distinct subset of GM-CSF-producing T helper cells that is essential for autoimmune neuroinflammation," Cell Research, vol. 24, no. 12, pp. 1387-1402, 2014.

[63] A. Shiomi, T. Usui, Y. Ishikawa, M. Shimizu, K. Murakami, and T. Mimori, "GM-CSF but not IL-17 is critical for the development of severe interstitial lung disease in SKG mice," The Journal of Immunology, vol. 193, no. 2, pp. 849-859, 2014.

[64] R. Noster, R. Riedel, M.-F. Mashreghi et al., "IL-17 and GM-CSF expression are antagonistically regulated by human $\mathrm{T}$ helper cells," Science Translational Medicine, vol. 6, Article ID 241ra80, 2014.

[65] M. J. McGeachy, "GM-CSF: the secret weapon in the $\mathrm{T}_{H} 17$ arsenal," Nature Immunology, vol. 12, no. 6, pp. 521-522, 2011.

[66] D. J. Cousins, T. H. Lee, and D. Z. Staynov, "Cytokine coexpression during human Th1/Th2 cell differentiation: direct evidence for coordinated expression of Th2 cytokines," Journal of Immunology, vol. 169, no. 5, pp. 2498-2506, 2002.

[67] T. R. Mosmann, H. Cherwinski, M. W. Bond, M. A. Giedlin, and R. L. Coffman, "Two types of murine helper T cell clone. I. Definition according to profiles of lymphokine activities and secreted proteins," The Journal of Immunology, vol. 136, no. 7, pp. 2348-2357, 1986.

[68] Y. Komiyama, S. Nakae, T. Matsuki et al., "IL-17 plays an important role in the development of experimental autoimmune encephalomyelitis," Journal of Immunology, vol. 177, no. 1, pp. 566-573, 2006.
[69] H. H. Hofstetter, S. M. Ibrahim, D. Koczan et al., "Therapeutic efficacy of IL-17 neutralization in murine experimental autoimmune encephalomyelitis," Cellular Immunology, vol. 237, no. 2, pp. 123-130, 2005.

[70] S. Nakae, A. Nambu, K. Sudo, and Y. Iwakura, "Suppression of immune induction of collagen-induced arthritis in IL-17deficient mice," Journal of Immunology, vol. 171, no. 11, pp. 61736177, 2003.

[71] H. Kellner, "Targeting interleukin-17 in patients with active rheumatoid arthritis: rationale and clinical potential," Therapeutic Advances in Musculoskeletal Disease, vol. 5, no. 3, pp. 141152, 2013.

[72] W. B. van den Berg and I. B. McInnes, "Th17 cells and IL-17 A-Focus on immunopathogenesis and immunotherapeutics," Seminars in Arthritis and Rheumatism, vol. 43, no. 2, pp. 158170,2013

[73] M. Kleinewietfeld and D. A. Hafler, "The plasticity of human Treg and Th17 cells and its role in autoimmunity," Seminars in Immunology, vol. 25, no. 4, pp. 305-312, 2013.

[74] E. V. Acosta-Rodriguez, L. Rivino, J. Geginat et al., "Surface phenotype and antigenic specificity of human interleukin 17producing T helper memory cells," Nature Immunology, vol. 8, no. 6, pp. 639-646, 2007.

[75] K. Ghoreschi, A. Laurence, X.-P. Yang et al., "Generation of pathogenic $\mathrm{T}_{H} 17$ cells in the absence of TGF- $\beta$ signalling," Nature, vol. 467, no. 7318, pp. 967-971, 2010.

[76] L. Cosmi, R. Cimaz, L. Maggi et al., "Evidence of the transient nature of the Th17 phenotype of CD4+CD161+ T cells in the synovial fluid of patients with juvenile idiopathic arthritis," Arthritis and Rheumatism, vol. 63, no. 8, pp. 2504-2515, 2011.

[77] A. Peters, Y. Lee, and V. K. Kuchroo, "The many faces of Th17 cells," Current Opinion in Immunology, vol. 23, no. 6, pp. 702706, 2011.

[78] F. Annunziato, L. Cosmi, V. Santarlasci et al., "Phenotypic and functional features of human Th17 cells," The Journal of Experimental Medicine, vol. 204, no. 8, pp. 1849-1861, 2007.

[79] L. Maggi, V. Santarlasci, M. Capone et al., "CD161 is a marker of all human IL-17-producing T-cell subsets and is induced by RORC," European Journal of Immunology, vol. 40, no. 8, pp. 2174-2181, 2010.

[80] L. Cosmi, R. De Palma, V. Santarlasci et al., "Human interleukin 17-producing cells originate from a CD161 ${ }^{+} \mathrm{CD} 4^{+} \mathrm{T}$ cell precursor," Journal of Experimental Medicine, vol. 205, no. 8, pp. $1903-$ 1916, 2008.

[81] C. Piper, A. M. Pesenacker, D. Bending et al., "Brief report: T cell expression of granulocyte-macrophage colony-stimulating factor in juvenile arthritis is contingent upon Th17 plasticity," Arthritis \& Rheumatology, vol. 66, no. 7, pp. 1955-1960, 2014.

[82] H. Kebir, I. Ifergan, J. I. Alvarez et al., "Preferential recruitment of interferon- $\gamma$-expressing TH17 cells in multiple sclerosis," Annals of Neurology, vol. 66, no. 3, pp. 390-402, 2009.

[83] K. Hirota, J. H. Duarte, M. Veldhoen et al., "Fate mapping of IL-17-producing T cells in inflammatory responses," Nature Immunology, vol. 12, no. 3, pp. 255-263, 2011.

[84] J. R. Lukens, M. J. Barr, D. D. Chaplin, H. Chi, and T.-D. Kanneganti, "Inflammasome-derived IL- $1 \beta$ regulates the production of GM-CSF by CD $4^{+}$T cells and $\gamma \delta$ T cells," Journal of Immunology, vol. 188, no. 7, pp. 3107-3115, 2012.

[85] C. E. Zielinski, F. Mele, D. Aschenbrenner et al., "Pathogeninduced human TH17 cells produce IFN- $\gamma$ or IL-10 and are regulated by IL-1 $\beta$," Nature, vol. 484, no. 7395, pp. 514-518, 2012. 
[86] R. I. Mazzucchelli, A. Riva, and S. K. Durum, "The human IL-7 receptor gene: deletions, polymorphisms and mutations," Seminars in Immunology, vol. 24, no. 3, pp. 225-230, 2012.

[87] S. M. Churchman and F. Ponchel, "Interleukin-7 in rheumatoid arthritis," Rheumatology, vol. 47, no. 6, pp. 753-759, 2008.

[88] H. Brühl, J. Cihak, M. Niedermeier et al., "Important role of interleukin-3 in the early phase of collagen-induced arthritis," Arthritis \& Rheumatism, vol. 60, no. 5, pp. 1352-1361, 2009.

[89] C. Chavany, C. Vicario-Abejón, G. Miller, and M. Jendoubi, "Transgenic mice for interleukin 3 develop motor neuron degeneration associated with autoimmune reaction against spinal cord motor neurons," Proceedings of the National Academy of Sciences of the United States of America, vol. 95, no. 19, pp. 11354-11359, 1998.

[90] R. Yamada, T. Tanaka, M. Unoki et al., "Association between a single-nucleotide polymorphism in the promoter of the human interleukin-3 gene and rheumatoid arthritis in Japanese patients, and maximum-likelihood estimation of combinatorial effect that two genetic loci have on susceptibility to the disease," American Journal of Human Genetics, vol. 68, no. 3, pp. 674-685, 2001.

[91] Y. Nakamura, P. Christodoulopoulos, L. Cameron et al., "Upregulation of the transcription factor GATA-3 in upper airway mucosa after in vivo and in vitro allergen challenge," The Journal of Allergy and Clinical Immunology, vol. 105, no. 6, part 1, pp. 1146-1152, 2000.

[92] H. Park, Z. Li, X. O. Yang et al., "A distinct lineage of CD4 T cells regulates tissue inflammation by producing interleukin 17," Nature Immunology, vol. 6, no. 11, pp. 1133-1141, 2005.

[93] S. Haak, A. L. Croxford, K. Kreymborg et al., "IL-17A and IL-17F do not contribute vitally to autoimmune neuro-inflammation in mice," The Journal of Clinical Investigation, vol. 119, no. 1, pp. 61-69, 2009.

[94] J. L. McQualter, R. Darwiche, C. Ewing et al., "Granulocyte macrophage colony-stimulating factor: a new putative therapeutic target in multiple sclerosis," Journal of Experimental Medicine, vol. 194, no. 7, pp. 873-881, 2001.

[95] E. D. Ponomarev, L. P. Shriver, K. Maresz, J. Pedras-Vasconcelos, D. Verthelyi, and B. N. Dittel, "GM-CSF production by autoreactive $\mathrm{T}$ cells is required for the activation of microglial cells and the onset of experimental autoimmune encephalomyelitis," Journal of Immunology, vol. 178, no. 1, pp. 39-48, 2007.

[96] O. Perrella, P. B. Carrieri, R. de Mercato, and G. A. Buscaino, "Markers of activated $\mathrm{T}$ lymphocytes and $\mathrm{T}$ cell receptor gamma/delta+ in patients with multiple sclerosis," European Neurology, vol. 33, no. 2, pp. 152-155, 1993.

[97] P. B. Carrieri, V. Provitera, T. de Rosa, G. Tartaglia, F. Gorga, and O. Perrella, "Profile of cerebrospinal fluid and serum cytokines in patients with relapsing-remitting multiple sclerosis: a correlation with clinical activity," Immunopharmacology and Immunotoxicology, vol. 20, no. 3, pp. 373-382, 1998.

[98] H. G. Fischer, A. K. Bielinsky, B. Nitzgen, W. Däubener, and U. Hadding, "Functional dichotomy of mouse microglia developed in vitro: differential effects of macrophage and granulocyte/macrophage colony-stimulating factor on cytokine secretion and antitoxoplasmic activity," Journal of Neuroimmunology, vol. 45, no. 1-2, pp. 193-201, 1993.

[99] H. González, D. Elgueta, A. Montoya, and R. Pacheco, "Neuroimmune regulation of microglial activity involved in neuroinflammation and neurodegenerative diseases," Journal of Neuroimmunology, vol. 274, no. 1-2, pp. 1-13, 2014.
[100] L. Qian, K. S. Tan, S.-J. Wei et al., "Microglia-mediated neurotoxicity is inhibited by morphine through an opioid receptorindependent reduction of NADPH oxidase activity," Journal of Immunology, vol. 179, no. 2, pp. 1198-1209, 2007.

[101] C. C. Ferrari, M. C. Pott Godoy, R. Tarelli, M. Chertoff, A. M. Depino, and F. J. Pitossi, "Progressive neurodegeneration and motor disabilities induced by chronic expression of IL-1beta in the substantia nigra," Neurobiology of Disease, vol. 24, no. 1, pp. 183-193, 2006.

[102] R. Gordon, V. Anantharam, and A. G. Kanthasamy, "Proteolytic activation of proapoptotic kinase protein kinase $C \delta$ by tumor necrosis factor $\alpha$ death receptor signaling in dopaminergic neurons during neuroinflammation," Journal of Neuroinflammation, vol. 9, article 82, 2012.

[103] H. González and R. Pacheco, "T-cell-mediated regulation of neuroinflammation involved in neurodegenerative diseases," Journal of Neuroinflammation, vol. 11, no. 1, article 201, 2014.

[104] I. L. King, T. L. Dickendesher, and B. M. Segal, "Circulating Ly-6C+ myeloid precursors migrate to the CNS and play a pathogenic role during autoimmune demyelinating disease," Blood, vol. 113, no. 14, pp. 3190-3197, 2009.

[105] B. Aube, S. A. Levesque, A. Pare et al., "Neutrophils mediate blood-spinal cord barrier disruption in demyelinating neuroinflammatory diseases," The Journal of Immunology, vol. 193, no. 5, pp. 2438-2454, 2014.

[106] M. Ahn, W. Yang, H. Kim, J.-K. Jin, C. Moon, and T. Shin, "Immunohistochemical study of arginase-1 in the spinal cords of Lewis rats with experimental autoimmune encephalomyelitis," Brain Research, vol. 1453, pp. 77-86, 2012.

[107] M. J. Carson, J. M. Doose, B. Melchior, C. D. Schmid, and C. C. Ploix, "CNS immune privilege: hiding in plain sight," Immunological Reviews, vol. 213, no. 1, pp. 48-65, 2006.

[108] A. Schottelius, "The role of GM-CSF in multiple sclerosis," Drug Research (Stuttg), vol. 63, supplement 1, article S8, 2013.

[109] A. L. Cornish, I. K. Campbell, B. S. McKenzie, S. Chatfield, and I. P. Wicks, "G-CSF and GM-CSF as therapeutic targets in rheumatoid arthritis," Nature Reviews Rheumatology, vol. 5, no. 10, pp. 554-559, 2009.

[110] D. Mulherin, O. Fitzgerald, and B. Bresnihan, "Synovial tissue macrophage populations and articular damage in rheumatoid arthritis," Arthritis and Rheumatism, vol. 39, no. 1, pp. 115-124, 1996.

[111] W. D. Xu, G. S. Firestein, R. Taetle, K. Kaushansky, and N. J. Zvaifler, "Cytokines in chronic inflammatory arthritis. II. Granulocyte-macrophage colony-stimulating factor in rheumatoid synovial effusions," The Journal of Clinical Investigation, vol. 83, no. 3, pp. 876-882, 1989.

[112] C. Fiehn, M. Wermann, A. Pezzutto, M. Hufner, and B. Heilig, "GM-CSF plasma concentrations in rheumatoid arthritis, systemic lupus erythematosus and spondyloarthropathy," Zeitschrift für Rheumatologie, vol. 51, no. 3, pp. 121-126, 1992.

[113] B. P. C. Hazenberg, M. A. van Leeuwen, M. H. van Rijswijk, A. C. Stern, and E. Vellenga, "Correction of granulocytopenia in Felty's syndrome by granulocyte-macrophage colonystimulating factor. Simultaneous induction of interleukin-6 release and flare-up of the arthritis," Blood, vol. 74, no. 8, pp. 2769-2770, 1989.

[114] M. Gattorno, P. Facchetti, F. Ghiotto et al., "Synovial fluid $\mathrm{T}$ cell clones from oligoarticular juvenile arthritis patients display a prevalent Th1/Th0-type pattern of cytokine secretion irrespective of immunophenotype," Clinical \& Experimental Immunology, vol. 109, no. 1, pp. 4-11, 1997. 
[115] T. Leizer, J. Cebon, J. E. Layton, and J. A. Hamilton, "Cytokine regulation of colony-stimulating factor production in cultured human synovial fibroblasts: I. Induction of GM-CSF and G-CSF production by interleukin-1 and tumor necrosis factor," Blood, vol. 76, no. 10, pp. 1989-1996, 1990.

[116] I. K. Campbell, U. Novak, J. Cebon, J. E. Layton, and J. A. Hamilton, "Human articular cartilage and chondrocytes produce hemopoietic colony-stimulating factors in culture in response to IL-1," The Journal of Immunology, vol. 147, no. 4, pp. 12381246, 1991.

[117] I. K. Campbell, M. J. Rich, R. J. Bischof, A. R. Dunn, D. Grail, and J. A. Hamilton, "Protection from collagen-induced arthritis in granulocyte-macrophage colony-stimulating factor-deficient mice," Journal of Immunology, vol. 161, no. 7, pp. 3639-3644, 1998.

[118] A. D. Cook, E. L. Braine, I. K. Campbell, M. J. Rich, and J. A. Hamilton, "Blockade of collagen-induced arthritis post-onset by antibody to granulocyte-macrophage colony-stimulating factor (GM-CSF): requirement for GM-CSF in the effector phase of disease," Arthritis Research, vol. 3, no. 5, pp. 293-298, 2001.

[119] I. K. Campbell, A. Bendele, D. A. Smith, and J. A. Hamilton, "Granulocyte-macrophage colony stimulating factor exacerbates collagen induced arthritis in mice," Annals of the Rheumatic Diseases, vol. 56, no. 6, pp. 364-368, 1997.

[120] M. Hashimoto, K. Hirota, H. Yoshitomi et al., "Complement drives Th17 cell differentiation and triggers autoimmune arthritis," The Journal of Experimental Medicine, vol. 207, no. 6, pp. 1135-1143, 2010.

[121] G. R. Burmester, M. E. Weinblatt, I. B. McInnes et al., "Efficacy and safety of mavrilimumab in subjects with rheumatoid arthritis," Annals of the Rheumatic Diseases, vol. 72, no. 9, pp. 1445-1452, 2013.

[122] F. Behrens, P. P. Tak, M. Østergaard et al., "MOR103, a human monoclonal antibody to granulocyte-macrophage colonystimulating factor, in the treatment of patients with moderate rheumatoid arthritis: results of a phase Ib/IIa randomised, double-blind, placebo-controlled, dose-escalation trial," Annals of the Rheumatic Diseases, 2014.

[123] J. F. Seymour and J. J. Presneill, "Pulmonary alveolar proteinosis: progress in the first 44 years," American Journal of Respiratory and Critical Care Medicine, vol. 166, no. 2, pp. 215-235, 2002.

[124] B. C. Trapnell, J. A. Whitsett, and K. Nakata, "Pulmonary alveolar proteinosis," The New England Journal of Medicine, vol. 349, no. 26, pp. 2527-2539, 2003.

[125] B. Carey and B. C. Trapnell, "The molecular basis of pulmonary alveolar proteinosis," Clinical Immunology, vol. 135, no. 2, pp. 223-235, 2010.

[126] G. Dranoff, A. D. Crawford, M. Sadelain et al., "Involvement of granulocyte-macrophage colony-stimulating factor in pulmonary homeostasis," Science, vol. 264, no. 5159, pp. 713-716, 1994.

[127] B. C. Trapnell and J. A. Whitsett, "GM-CSF regulates pulmonary surfactant homeostasis and alveolar macrophage-mediated innate host defense," Annual Review of Physiology, vol. 64, pp. 775-802, 2002.

[128] M. Luisetti, G. Rodi, C. Perotti et al., "Plasmapheresis for treatment of pulmonary alveolar proteinosis," European Respiratory Journal, vol. 33, no. 5, pp. 1220-1222, 2009.
[129] R. Tazawa, B. C. Trapnell, Y. Inoue et al., "Inhaled granulocyte/macrophage-colony stimulating factor as therapy for pulmonary alveolar proteinosis," American Journal of Respiratory and Critical Care Medicine, vol. 181, no. 12, pp. 1345-1354, 2010.

[130] S. B. Venkateshiah, T. D. Yan, T. L. Bonfield et al., "An open-label trial of granulocyte macrophage colony stimulating factor therapy for moderate symptomatic pulmonary alveolar proteinosis," Chest, vol. 130, no. 1, pp. 227-237, 2006.

[131] M. S. Kavuru, A. Malur, I. Marshall et al., "An open-label trial of rituximab therapy in pulmonary alveolar proteinosis," European Respiratory Journal, vol. 38, no. 6, pp. 1361-1367, 2011.

[132] A. Malur, M. S. Kavuru, I. Marshall et al., "Rituximab therapy in pulmonary alveolar proteinosis improves alveolar macrophage lipid homeostasis," Respiratory Research, vol. 13, article 46, 2012.

[133] T. J. Gross and G. W. Hunninghake, "Idiopathic pulmonary fibrosis," The New England Journal of Medicine, vol. 345, no. 7, pp. 517-525, 2001.

[134] T. E. King Jr., A. Pardo, and M. Selman, "Idiopathic pulmonary fibrosis," The Lancet, vol. 378, no. 9807, pp. 1949-1961, 2011.

[135] L. M. Crosby and C. M. Waters, "Epithelial repair mechanisms in the lung," American Journal of Physiology-Lung Cellular and Molecular Physiology, vol. 298, no. 6, pp. L715-L731, 2010.

[136] J. G. N. Garcia, N. Parhami, D. Killam, P. L. Garcia, and B. A. Keogh, "Bronchoalveolar lavage fluid evaluation in rheumatoid arthritis," The American Review of Respiratory Disease, vol. 133, no. 3, pp. 450-454, 1986.

[137] J. G. N. Garcia, H. L. James, S. Zinkgraf, M. B. Perlman, and B. A. Keogh, "Lower respiratory tract abnormalities in rheumatoid interstitial lung disease. Potential role of neutrophils in lung injury," American Review of Respiratory Disease, vol. 136, no. 4, pp. 811-817, 1987.

[138] E. S. White, M. H. Lazar, and V. J. Thannickal, "Pathogenetic mechanisms in usual interstitial pneumonia/idiopathic pulmonary fibrosis," Journal of Pathology, vol. 201, no. 3, pp. 343354, 2003.

[139] Y. Shimizu, H. Kuwabara, A. Ono et al., "Intracellular Th1/Th2 balance of pulmonary $\mathrm{CD}^{+} \mathrm{T}$ cells in patients with active interstitial pneumonia evaluated by serum KL-6," Immunopharmacology and Immunotoxicology, vol. 28, no. 2, pp. 295-304, 2006.

[140] P. Pignatti, G. Brunetti, D. Moretto et al., "Role of the chemokine receptors CXCR3 and CCR4 in human pulmonary fibrosis," The American Journal of Respiratory and Critical Care Medicine, vol. 173, no. 3, pp. 310-317, 2006.

[141] J. Knobloch, H. Peters, D. Jungck, K. Müller, J. Strauch, and A. Koch, "TNF $\alpha$-induced GM-CSF release from human airway smooth muscle cells depends on activation of an ET-1 autoregulatory positive feedback mechanism," Thorax, vol. 64, no. 12, pp. 1044-1052, 2009.

[142] H. Taniguchi, S. Katoh, J. Kadota et al., "Interleukin 5 and granulocyte-macrophage colony-stimulating factor levels in bronchoalveolar lavage fluid in interstitial lung disease," European Respiratory Journal, vol. 16, no. 5, pp. 959-964, 2000.

[143] C. Walker, W. Bauer, R. K. Braun et al., "Activated T cells and cytokines in bronchoalveolar lavages from patients with various lung diseases associated with eosinophilia," American Journal of Respiratory and Critical Care Medicine, vol. 150, no. 4, pp. 10381048, 1994. 
[144] Z. Xing, T. Braciak, Y. Ohkawara et al., "Gene transfer for cytokine functional studies in the lung: the multifunctional role of GM-CSF in pulmonary inflammation," Journal of Leukocyte Biology, vol. 59, no. 4, pp. 481-488, 1996.

[145] Z. Xing, Y. Ohkawara, M. Jordana, F. L. Graham, and J. Gauldie, "Transfer of granulocyte-macrophage colony-stimulating factor gene to rat lung induces eosinophilia, monocytosis, and fibrotic reactions," The Journal of Clinical Investigation, vol. 97, no. 4, pp. 1102-1110, 1996.

[146] G. R. Johnson, T. J. Gonda, D. Metcalf, I. K. Kariharan, and S. Cory, "A lethal myeloproliferative syndrome in mice transplanted with bone marrow cells infected with a retrovirus expressing granulocyte-macrophage colony stimulating factor," The EMBO Journal, vol. 8, no. 2, pp. 441-448, 1989.

[147] S. Worgall, R. Singh, P. L. Leopold et al., "Selective expansion of alveolar macrophages in vivo by adenovirus-mediated transfer of the murine granulocyte-macrophage colony-stimulating factor cDNA," Blood, vol. 93, no. 2, pp. 655-666, 1999.

[148] R. Vij and M. E. Strek, "Diagnosis and treatment of connective tissue disease-associated interstitial lung disease," Chest, vol. 143, no. 3, pp. 814-824, 2013.

[149] A. de Lauretis, S. Veeraraghavan, and E. Renzoni, "Review series: aspects of interstitial lung disease: connective tissue disease-associated interstitial lung disease: how does it differ from IPF? How should the clinical approach differ?" Chronic Respiratory Disease, vol. 8, no. 1, pp. 53-82, 2011.

[150] N. Sakaguchi, T. Takahashi, H. Hata et al., "Altered thymic Tcell selection due to a mutation of the ZAP-70 gene causes autoimmune arthritis in mice," Nature, vol. 426, no. 6965, pp. 454-460, 2003.

[151] R. C. Keith, J. L. Powers, E. F. Redente et al., "A novel model of rheumatoid arthritis-associated interstitial lung disease in SKG mice," Experimental Lung Research, vol. 38, no. 2, pp. 55-66, 2012.

[152] B. Khor, A. Gardet, and R. J. Xavier, "Genetics and pathogenesis of inflammatory bowel disease," Nature, vol. 474, no. 7351, pp. 307-317, 2011.

[153] J. K. Yamamoto-Furusho and J. R. Korzenik, "Crohn's disease: innate immunodeficiency?" World Journal of Gastroenterology, vol. 12, no. 42, pp. 6751-6755, 2006.

[154] J. R. Korzenik, "Is Crohn's disease due to defective immunity?" Gut, vol. 56, no. 1, pp. 2-5, 2007.

[155] E. Bernasconi, L. Favre, M. H. Maillard et al., "Granulocytemacrophage colony-stimulating factor elicits bone marrowderived cells that promote efficient colonic mucosal healing," Inflammatory Bowel Diseases, vol. 16, no. 3, pp. 428-441, 2010.

[156] J. Däbritz, "Granulocyte macrophage colony-stimulating factor and the intestinal innate immune cell homeostasis in Crohn's disease," American Journal of Physiology-Gastrointestinal and Liver Physiology, vol. 306, no. 6, pp. G455-G465, 2014.

[157] R. Gennari, J. W. Alexander, L. Gianotti, T. Eaves-Pyles, and S. Hartmann, "Granulocyte macrophage colony-stimulating factor improves survival in two models of gut-derived sepsis by improving gut barrier function and modulating bacterial clearance," Annals of Surgery, vol. 220, no. 1, pp. 68-76, 1994.

[158] X. Han, K. Uchida, I. Jurickova et al., "Granulocyte-macrophage colony-stimulating factor autoantibodies in murine ileitis and progressive ileal Crohn's disease," Gastroenterology, vol. 136, no. 4, pp. e1261-e1263, 2009.
[159] Y. Xu, N. H. Hunt, and S. Bao, "The role of granulocyte macrophage-colony-stimulating factor in acute intestinal inflammation," Cell Research, vol. 18, no. 12, pp. 1220-1229, 2008.

[160] L. Egea, Y. Hirata, and M. F. Kagnoff, "GM-CSF: a role in immune and inflammatory reactions in the intestine," Expert Review of Gastroenterology and Hepatology, vol. 4, no. 6, pp. 723-731, 2010.

[161] S. K. Sainathan, E. M. Hanna, Q. Gong et al., "Granulocyte macrophage colony-stimulating factor ameliorates DSSinduced experimental colitis," Inflammatory Bowel Diseases, vol. 14, no. 1, pp. 88-99, 2008.

[162] M. Biondo, Z. Nasa, A. Marshall, B. H. Toh, and F. Alderuccio, "Local transgenic expression of granulocyte macrophagecolony stimulating factor initiates autoimmunity," Journal of Immunology, vol. 166, no. 3, pp. 2090-2099, 2001.

[163] D. Spight, B. Trapnell, B. Zhao, P. Berclaz, and T. P. Shanley, "Granulocyte-macrophage-colony-stimulating factordependent peritoneal macrophage responses determine survival in experimentally induced peritonitis and sepsis in mice," Shock, vol. 30, no. 4, pp. 434-442, 2008.

[164] S. Sainathan, K. Bishnupuri, C. Houchen, S. Anant, and B. K. Dieckgraefe, Gm-Csf Increases Resistance to Apoptotic Cell Death and Enhances Crypt StemCell Survival in a RadiationInduced Intestinal Injury Model, American Gastroenterological Association, Washington, DC, USA, 2005.

[165] B. K. Dieckgraefe and J. R. Korzenik, "Treatment of active Crohn's disease with recombinant human granulocytemacrophage colony-stimulating factor," The Lancet, vol. 360, no. 9344, pp. 1478-1480, 2002.

[166] J. R. Korzenik, B. K. Dieckgraefe, J. F. Valentine, D. F. Hausman, and M. J. Gilbert, "Sargramostim for active Crohn's disease," The New England Journal of Medicine, vol. 352, no. 21, pp. 2193-2201, 2005.

[167] J. F. Valentine, R. N. Fedorak, B. Feagan et al., "Steroid-sparing properties of sargramostim in patients with corticosteroiddependent Crohn's disease: a randomised, double-blind, placebo-controlled, phase 2 study," Gut, vol. 58, no. 10, pp. 1354-1362, 2009.

[168] L. Roth, J. K. MacDonald, J. W. D. McDonald, and N. Chande, "Sargramostim (GM-CSF) for induction of remission in crohn's disease: a cochrane inflammatory bowel disease and functional bowel disorders systematic review of randomized trials," Inflammatory Bowel Diseases, vol. 18, no. 7, pp. 1333-1339, 2012.

[169] E. C. Cates, R. Fattouh, J. Wattie et al., "Intranasal exposure of mice to house dust mite elicits allergic airway inflammation via a GM-CSF-mediated mechanism," The Journal of Immunology, vol. 173, no. 10, pp. 6384-6392, 2004.

[170] M. A. M. Willart, K. Deswarte, P. Pouliot et al., "Interleukin$1 \alpha$ controls allergic sensitization to inhaled house dust mite via the epithelial release of GM-CSF and IL-33," The Journal of Experimental Medicine, vol. 209, no. 8, pp. 1505-1517, 2012.

[171] K. T. Nouri-Aria, K. Masuyama, M. R. Jacobson et al., "Granulocyte/macrophage-colony stimulating factor in allergen-induced rhinitis: cellular localization, relation to tissue eosinophilia and influence of topical corticosteroid," International Archives of Allergy and Immunology, vol. 117, no. 4, pp. 248-254, 1998.

[172] N. Yamashita, H. Tashimo, H. Ishida et al., "Attenuation of airway hyperresponsiveness in a murine asthma model by neutralization of granulocyte-macrophage colony-stimulating 
factor (GM-CSF)," Cellular Immunology, vol. 219, no. 2, pp. 9297, 2002.

[173] R. Vlahos, S. Bozinovski, J. A. Hamilton, and G. P. Anderson, "Therapeutic potential of treating chronic obstructive pulmonary disease (COPD) by neutralising granulocyte macrophage-colony stimulating factor (GM-CSF)," Pharmacology and Therapeutics, vol. 112, no. 1, pp. 106-115, 2006.

[174] G.-R. Burmester, E. Feist, M. A. Sleeman, B. Wang, B. White, and F. Magrini, "Mavrilimumab, a human monoclonal antibody targeting GM-CSF receptor- $\alpha$, in subjects with rheumatoid arthritis: a randomised, double-blind, placebo-controlled, phase I, first-in-human study," Annals of the Rheumatic Diseases, vol. 70, no. 9, pp. 1542-1549, 2011. 


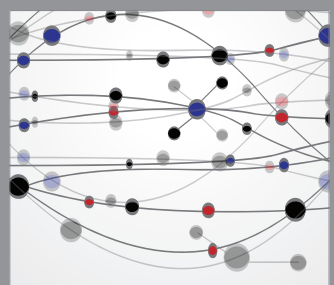

The Scientific World Journal
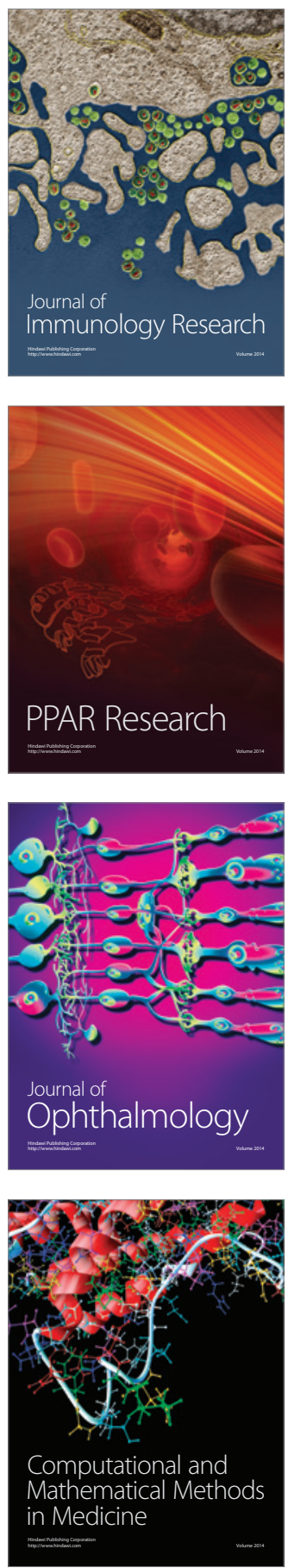

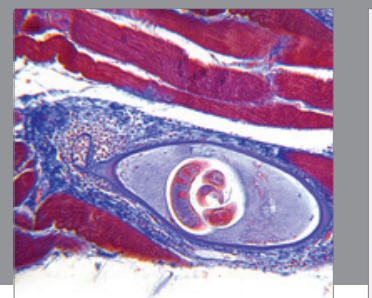

Gastroenterology

Research and Practice
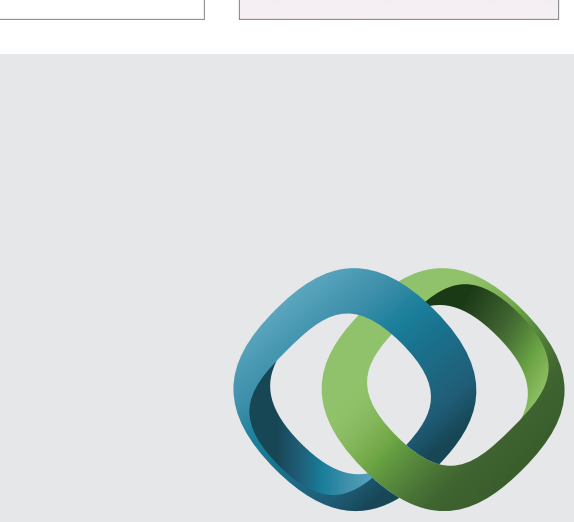

\section{Hindawi}

Submit your manuscripts at

http://www.hindawi.com
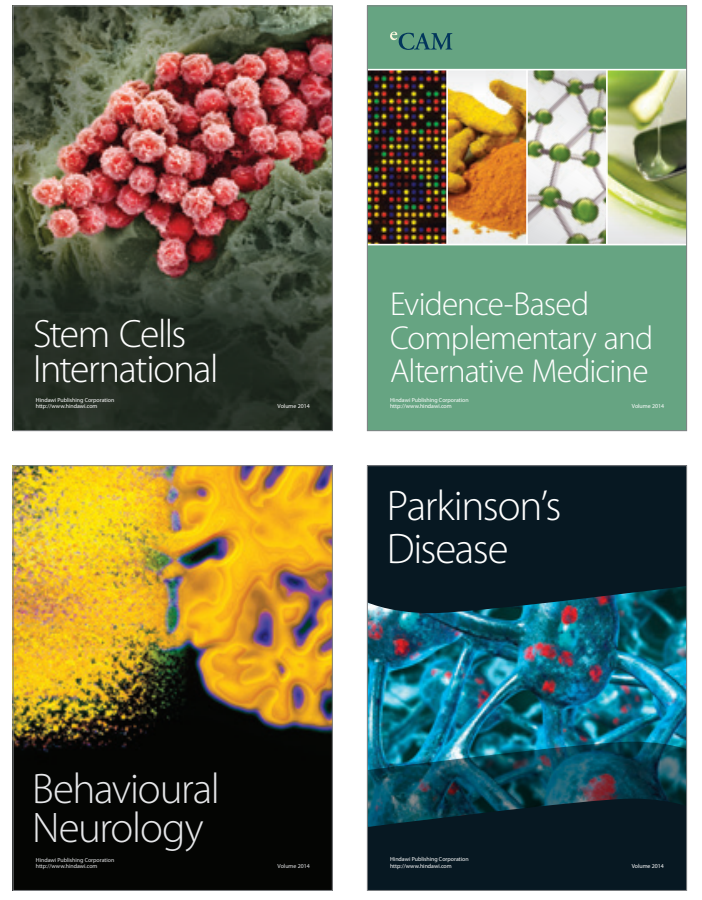
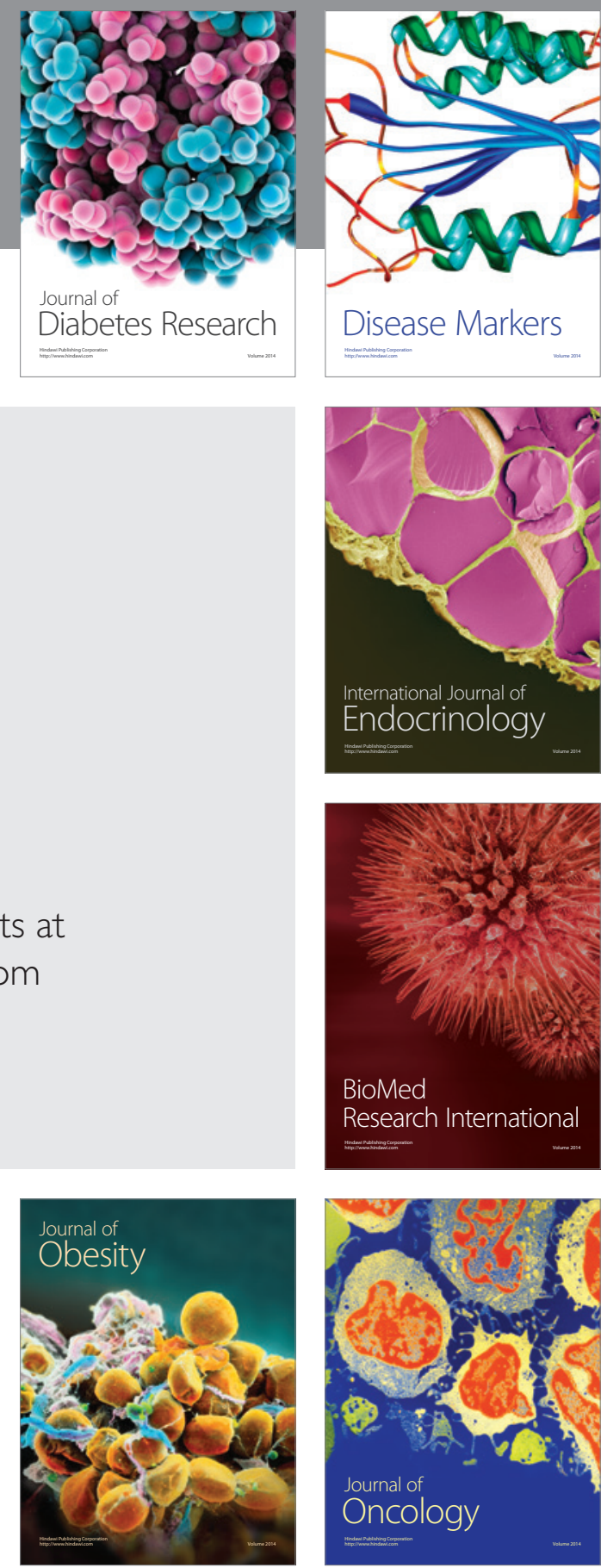

Disease Markers
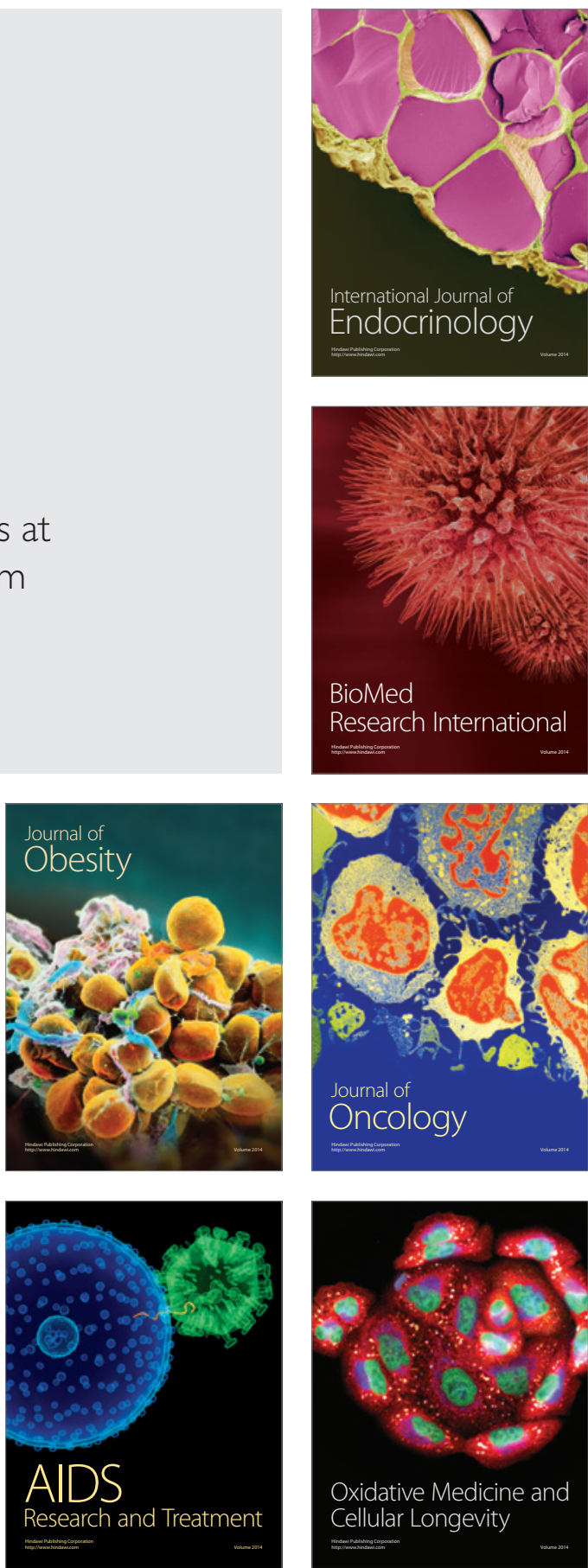